\title{
The Impact of the Financial Wellbeing of the Elderly of Kazakhstan on Their Family Life
}

\author{
Zaira T. Satpayeva ${ }^{1 *}$, Assel S. Bekbossinova ${ }^{2}$, Maira M. Ryskulova ${ }^{2}$ \\ ${ }^{1}$ Institute of Economics of the Science Committee of the Ministry of Education \\ and Science of the Republic of Kazakhstan, 29 Kurmangazy str., 050010, Almaty, Kazakhstan \\ ${ }^{2}$ NARXOZ University, 55 Zhandosova str., 050035, Almaty, Kazakhstan
}

\begin{abstract}
Today, many countries in the world are concerned about the well-being of pensioners, as their number is growing every year and pension systems cannot cope with ensuring a decent old age. The well-being of pensioners is part of the well-being of society, and the pension system is an institution for ensuring the well-being of pensioners. Therefore, it is important to understand the relationship between the financial well-being of older people and the country's pension system. It is also important to understand that the family is an integral part of a person and therefore the well-being of each family member affects family relationships.

This article is devoted to the assessment of the financial well-being of pensioners in Kazakhstan as a key factor affecting the family relations of a pensioner with partner, children, and grandchildren. Primary and secondary data were used for this study. The primary data were collected through interviews, which allowed us to obtain a subjective definition of financial well-being on the part of pensioners and its impact on family relations. This data was processed and encoded using the Atlas.ti program. Data from the Bureau of National Statistics made it possible to objectively assess the financial situation of Kazakhstani pensioners. The study found that the concept of financial well-being among Kazakhstani pensioners is more important for men than for women. Pensioners are not happy with their financial well-being, but this does not significantly affect their relationship with their families. The results of the study will allow us to assess the financial well-being of pensioners and can be used in the reform of social policy, pension provision of the country. Through the use of interviews financial literacy has been identified as one of the key factors, which depends on circumstances and the context.
\end{abstract}

Key words: pensioner, well-being, financial well-being, pension, family, financial literacy

For citation: Satpayeva, Z.T., Bekbossinova, A.S. \& Ryskulova, M.M. (2021). The impact of the Financial Wellbeing of the Elderly of Kazakhstan on Their Family Life. Economics: the Strategy and Practice, 16(3), 152-166, https://doi. org/10.51176/1997-9967-2021-3-152-166

* Corresponding author: Zaira T. Satpayeva - PhD, Institute of Economics of the Science Committee of the Ministry of Education and Science of the Republic of Kazakhstan, 29 Kurmangazy str., 050010, Almaty, Kazakhstan. e-mail:szt_kz@mail.ru

Conflict of interests: the authors declare that there is no conflict of interest

Financial support: This research has been supported by the Ministry of Education and Science of the Republic of Kazakhstan within the project «The science impact on Kazakhstan's socio-economic development: methodology, assessment models and development scenarios» (IRN AP08052745).

The article received: 10.06 .2021

The article approved for publication: 28.06 .2021

Date of publication: 30.09 .2021 


\title{
Қазақстанның қарт адамдарының қаржылық әл-ауқатының олардың отбасылық өміріне әсері
}

\author{
Сатпаева 3.T.1*, Бекбосинова А.С. ${ }^{2}$, Рыскулова М.М. \\ ${ }^{1}$ Қазақсстан Республикасы Білім және вылым министрлігі Ғылым комитетінің \\ Экономика институты, Құрмандазы к., 29, 050010, Алматы к.., Қазақстан \\ ${ }^{1}$ НАРХОЗ университеті, Жандосов көшесі, 55, 050035, Алматы, Қазақсстан
}

\begin{abstract}
Тұйін
Бүгінде әлемде көптеген елдер зейнеткерлердің әл-ауқатын ойлайды, өйткені олардың саны жыл сайын өсіп келеді және зейнетақы жүйелері лайықты қартаюды қамтамасыз ете алмайды. Зейнеткерлердің әл-ауқаты қоғамның әл-ауқатының бір бөлігі болып табылады, ал зейнетақы жүйесі - зейнеткерлердің әл-ауқатын қамтамасыз ету институты. Сондықтан қарт адамдардың қаржылық әл-ауқаты мен елдің зейнетақы жүйесі арасындағы өзара байланысты түсіну маңызды. Сондай-ақ, отбасы адамның ажырамас бөлігі екенін ұмытпау керек, сондықтан отбасының әр мүшесінің әл-ауқаты отбасылық қатынастарға әсер етеді.

Бұл мақала Қазақстан зейнеткерлерінің қаржылық әл-ауқатын зейнеткердің серіктесімен, балаларымен және немерелерімен отбасылық қарым-қатынасына әсер ететін негізгі фактор ретінде бағалауға арналған. Бұл зерттеуді жүргізу үшін бастапқы және қайталама деректер пайдаланылды. Бастапқы деректер сұхбат арқылы жиналды, бұл зейнеткерлердің қаржылық әл-ауқатының субъективті анықтамасын және оның отбасылық қатынастарға әсерін бағалауға мүмкіндік берді. Интервью барысында жинақталған ақпарат Atlas. ti бағдарламасы арқылы өңделді. Ұлттық статистика бюросының мәліметтері қазақстандық зейнеткерлердің қаржылық жағдайын әділ бағалауға мүмкіндік берді. Зерттеу барысында қазақстандық зейнеткерлер арасында қаржылық әл-ауқат ұғымы әйелдерге қарағанда ерлер үшін маңызды екені анықталды. Зейнеткерлер өздерінің қаржылық әл-ауқатына риза емес, бірақ бұл олардың отбасымен қарым-қатынасына айтарлықтай әсер етпейді. Зерттеу нәтижелері зейнеткерлердің қаржылық әл-ауқатын бағалауға мүмкіндік береді және оларды елдің әлеуметтік саясатын, зейнетақымен қамтамасыз етуді реформалауда қолдануға болады.

Сұхбат барысында қаржылық сауаттылық жағдайлармен контекстке байланысты негізгі факторлардың бірі ретінде анықталды.
\end{abstract}

Tүйін сөздер: зейнеткер, әл-ауқат, қаржылық әл-ауқат, отбасы, зейнетақы, қаржылықсауаттылық.

Дәйексөз алу үшін: Сатпаева 3.Т., Бекбосинова А.С., Рыскулова М.М. (2021). Қазақстанның қарт адамдарының қаржылық әл-ауқатының олардың отбасылық өміріне әсері. Экономика: стратегия және практика, 16(3), 152166 , https://doi.org/10.51176/1997-9967-2021-3-152-166

* Хат-хабаршы авторы: Сатпаева 3.T - PhD, Қазақстан Республикасы Білім және ғылым министрлігі Ғылым комитетінің Экономика институты, Құрманғазы к., 29, 050010, Алматы қ., Қазақстан, e-mail: szt kz@mail.ru

Мүдделер қақтығысы: авторлар мүдделер қақтығысының жоқтығын мәлімдейді.

Қаржыландыру. Мақала Қазақстан Республикасы Білім және ғылым министрлігінің «ғылымның Қазақстанның әлеуметтік-экономикалық дамуына әсері: әдіснамасы, бағалау модельдері және даму сценарийлері» гранттық қаржыландыру жобасы шеңберінде әзірленген (ЖТН АР08052745).

Мақала редакцияға түсті: 10.06 .2021

Жариялау туралы шешім қабылданды: 28.06.2021

Жарияланды: 30.09 .2021 


\title{
Влияние финансового благополучия пожилых людей Казахстана на их семейную жизнь
}

\author{
Сатпаева 3.T. ${ }^{*}$, Бекбосинова А.С. ${ }^{2}$, Рыскулова М.М. ${ }^{2}$ \\ ${ }^{1}$ Институт экономики Комитета науки Министерства образования и науки Республики \\ Казахстан, ул. Курмангазы,29, 050010, г. Алматы, Казахстан \\ ${ }^{2}$ Университет НАРХОЗ, ул. Жандосова, 55, 050035, г. Алматы, Казахстан
}

\begin{abstract}
Аннотация
Сегодня в мире многие страны озабочены вопросом благополучия пенсионеров, поскольку их число ежегодно растет и пенсионные системы не справляются с обеспечением достойной старости. Благополучие пенсионеров является частью благополучия общества, а пенсионная система является институтом обеспечения благополучия для пенсионеров. Поэтому важно понимать, взаимосвязь между финансовым благополучием пожилых людей и пенсионной системой страны. А также же важно помнить, что семья это неотъемлемая часть человека и поэтому благополучие каждого члена семьи влияет на семейные взаимоотношения.

Данная статья посвящена оценке финансового благополучия пенсионеров Казахстана, и как ключевого фактора, влияющего на семейные отношения пенсионера с его партнером, детьми и внуками. Для проведения данного исследования использовались первичные и вторичные данные. Первичные данные были собраны посредством интервью, которое позволило получить субъективное определение финансового благополучия со стороны пенсионеров и его влияния на семейные отношения. Эти данные были обработаны и закодированы с помощью программы Atlas.ti. Данные Бюро национальной статистики позволили объективно оценить финансовое положение казахстанских пенсионеров. В ходе исследования было обнаружено, что понятие финансового благополучия среди казахстанских пенсионеров для мужчин важнее, чем для женщин. Пенсионеры не довольны своим финансовым благосостоянием, но это не сильно влияет на их отношения с семьей. Результаты исследования позволят оценить финансовое благополучие пенсионеров и могут быть использованы в реформировании социальной политике, пенсионного обеспечения страны.

В ходе интервью финансовая грамотность была определена как один из ключевых факторов, который зависит от обстоятельств и контекста.

Ключевые слова: пенсионер, благополучие, финансовое благополучие, пенсия, семья, финансовая грамотность.
\end{abstract}

Для цитирования: Сатпаева З.Т., Бекбосинова А.С., Рыскулова М.М. (2021). Влияние финансового благополучия пожилых людей Казахстана на их семейную жизнь. Экономика: стратегия и практика, 16(3), 152-166, https://doi.org/10.51176/1997-9967-2021-3-152-166

* Корреспондирующий автор: Сатпаева 3.T. - PhD, Институт экономики Комитета науки Министерста образования и науки Республики Казахстан, ул. Курмангазы,29, 050010, г. Алматы, Казахстан, е-mail: szt_kz@mail.ru

Конфликт интересов: авторы заявляют об отсутствии конфликта интересов.

Финансирование. Статья подготовлена в рамках проекта грантового финансирования Министерства образования и науки Республики Казахстан «Влияние науки на социально-экономическое развитие Казахстана: методология, модели оценки и сценарии развития» (ИРН АР08052745).

Статья поступила в редакцию: 10.06 .2021

Принято решение о публикации: 28.06 .2021

Опубликовано: 30.09.2021 


\section{Introduction}

Decline in birthrate, social economy development, and many more factors result in the situation where the process of population aging has accelerated in many countries. The number of elderly people in general population size has increased in many countries and is still increasing. Therein the question arises of how to ensure elderly people not only with material values but also with other types of well-being such as physical and psychological life satisfaction, education, and others. Who is in charge of and can ensure well-being of elderly people (pensioners), can they reckon upon state pension or must save up for retirement during working age or contribute to pension funds and other issues surrounding elderly people well-being.

There are a number of factors, both objective and subjective, that affect the level of human wellbeing. One of the important factors is the presence of a family. This factor is an integral part of wellbeing, as it determines the level of comfort for the elderly. The presence of close people-a husband or wife, children, grandchildren for the elderly is an important component of comfort, the feeling that life has not been lived in vain determines the meaning of family happiness. Moreover, to have a happy family nearby, with good relationships, you need finances. We can safely say that financial well-being affects the family relationships of any person, so it is important to know how important this influence is for pensioners. Because of retirement, financial opportunities are reduced.

Population ageing occurs due to political and business environment in a country, its culture and traditions of nations living there. One of the main aims of a country is to create and build balanced, harmonic development of a society, which is directly connected with elderly people well-being, that is they must have high living standards and satisfaction with own life. Population aging is counted as ratio of "demographic dividends" to "demographic responsibilities", namely young -toelderly population size ratio. In line with studies of Yan (2013), is 10\% of people in a country are over 60 years old or $7 \%$ are 65 or older, then this country or society is aging [1]. Referring to this study, the society of Kazakhstan is aging, as the population size, which is older than 60 years old, makes up $10 \%$ (2 million people) according to the data of the National Uniform Pension Fund and Ministry of Labor and Social Protection.

Worldwide trend involving population aging puts under a threat to elderly people well-being, whereas their long living in retirement requires increase in financial capabilities [2]. Considering USA by indicators of average savings rate, even their indicators are at a low level, which means that people live longer than their savings, as life expectancy has been increasing [3, 4]. Meanwhile, in Kazakhstan, out of 10 million contributors of the National Uniform Pension Fund only 90 thousand have saved up in advance for lifelong minimum payments (less than $1 \%$ of total $-0,9 \%$ ). According to the data of UNPF 70 thousand men have 8 million KZT on their accounts and 20 thousand women 10 million. This is enough for receiving a life monthly pension and it is not a basic state pension, the average amount of which is currently 27thousand KZT, but saved own resources, which provide with a minimum pension, excluding state basic pension (52 $145 \mathrm{KZT}$ (135 USD) in 2019). The rest of 9910000 investors of UNPF has not saved enough funds according to the data of the fund the number of investors, who have reached the "adequacy point" will increase by 2.5 times in 5 years. There is still time, however, experts advise a plan for the future before pension age, so that people during the pension age were satisfied with financial well-being on which many life aspects depend.

This article discusses the financial wellbeing of pensioners and how it affects their family relationships, i.e. relationships with children and grandchildren, as well as with relatives and friends. The key question of the study is whether financial well-being affects the family relationships of Kazakhstani pensioners and what role does financial literacy and financial behavior play in this issue. Many studies have been conducted to determine financial well-being and different indicators have been used for different categories of the population. Moreover, basically,all the concepts used in previous studies are determined by financial experts. This article presents the interim results of the study of the financial well-being of pensioners using a qualitative research method, the tool of which is an interview. The interview apart from other research methods is the primary information collection method. An interviewer puts questions, receives answers, and makes notes, thereat observing the reaction and behavior of the respondents during the talk, which plays not unimportant part while information processing and analysis. The interview results are among the most reliable ones, therefore they are valuable. This study shows that educated pensioners are better off financially than not educated retirees, which has a positive effect on their family relationships.

\section{Literature review}

Financial well-being is among new research directions, though well-being has been broadly analyzed from various angles (Bobe and Cooper, 2018), including the sociological and psychological $[3,5,6]$. Throughout some studies, which have been 
provided, financial well-being has been defined and measured, that is considered objectively, drawing on multiple unbiased qualities including Porter and Garman in 1992 took income as indicating an instrument of financial well-being. Shim and others (2009) have an increased focus onthe financial well-being of students, using their debt level as financial well-being indicator [9]. There in a recent proof-of-concept study by Bruugenet et al. (2017) well-being has been determined as "perception of the ability to maintain current and expected intended standards of living and financial freedom" [3]. This definition stresses the importance of subjective feelings. Meaning to say that people apprize own financial well-being mainly stand on their own predilections and do unhinge on their own intrinsic financial state. Hence, according to Kapur (2005), people with uniform social and demographic profiles can estimate their financial well-being following no particular pattern [10].

Judgmental estimate of particular financial well-being has also been studied in other studies [9]. For instance, Malone et al. (2010) had it that people can assess their financial well-being in different ways depending on their stage of life [11]. The perception of financial well-being also depends on highly personalized standards of comparison [12]. All together subjective attributes reweigh objective ones in assessing of particularfinancial well-being [3]. Financial well-being management is highly important, as the quality of standards of living can either directly or indirectly depend on how people conceive their financial well-being [13]. In line with satisfaction, desire, hope, perfect health,and strong interpersonal relations, there can be added positive comprehension of financial well-being [14]. These physical and psychological factors can have a positive impact on labor capacity and financial behavior, which ultimately reduce social problems and improve social wellbeing which in contrast $[3,13]$. On the other part anegative image of financial well-being may cause anxiety, violence, tiredness and disturbance the general sense of well-being. It is conceivable that they may arise financially destructive behavior as delayed invoice payments and deprivation of property redemption rights. In this fashion, the rate of crime can double, social issues will increase and they will arise welfare dependency [16].

Financial well-being is determined by subjective and objective aspects as well, consequently, they must be regarded as two constructions [17]. For instance, Danes and Yang (2014) have regarded net value as non-based financial indicatorof financial well-being, while the adequacy of income is a subjective financial indicator of financial well-being [17]. The theory of family financial socialization (FFS) states that financial policy, knowledge, and skills directly affect financial behavior as well asthe general financial well-being of an individual. Financial socialization is more than education of how to manage finances successfully; it includes the development of policies, values and standards, which in the final count either support or disrupt financial capacity and well-being [18].

By virtue of Lusardi and Mitchell (2011), well-being on pension contacts directly with financial literacy and planning while working life [19]. Early experience contributes to financial skills and expertise, which help achieve healthy financial behavior [9]. The support of employers and workmates in early career stages can be fruitful for developing financial skills and positive saving behavior. However, the occurrence of financial literacy and planning among adults - is the acquisition of financial possibilities at an early age [19].

Personal and social well-being of a person is related to financial well-being. There is a possibility that pensioners without a stable and steady source of income, will be more worried about their life standards and will be less satisfied financially, than those who have financial sources [20]. Healthy customer behavior can improve living standards and level of satisfaction with it [21]. However, after retirement, people can change their customer behavior. Banks et al. (1998) state that pensioners should have smoothened their customer behavior in different periods of life in retirement, but in reality, they significantly reduce their consumption, which is called"theretirement - consumption puzzle" [22]. When people have low financial well-being, if their real consumption does not satisfy their needs, they are more inclined to talk or inform about it [23]. Therefore, their resolution on consumption has a great meaning for those who have gone on retirement to smooth and plan their consumption in retirement. Financial well-being is connected with all levels of living. Thus, at the individual level, it is closely connected with the quality of life and health (psychological and physical) [24]. Financial well-being improves social relationships and work productivity [3]. At the level of organizations, it promotes internal culture and external reputation [25]. At the social level, it reduces social and economic questions, enriches social norms and culture in a country [11]. Consequently, advancing elderly people, financial well-being is an effective way of improving their living standards and as a result population aging-negative consequences easing. Nevertheless, financial well-being of elderly people is still a new area of studies [3].

To a great extent, adult saving behavior is determined by socialization experience and saving behavior, developed in adolescent life and it is 
regarded that poor financial literacy among young adults is preserved in middle age as well [19, 26]. Comprehensive investigations of financial possibilities among young adults point to the fact that skills are developed through experience at school and home [27]. Financial education at schools in adolescent life increases the level of financial knowledge, leading to a shift in attitude and positive financial behavior [28, 29]. Programs of financial literacy alone are not enough forthe development of positive financial potential. Shimet al. (2009) state that target-driven financial education of parents is more important for positive financial behavior development among young adults than formal education [11]. Therefore, it is important to know the level of impact of family financial socialization on pensioners, and how they affect their children and grandchildren. What is the part ofthe government in this issue?

Summing up the results of the literature review, it is necessary to pay attention to the fact that financial well-being is one of the important indicators of the development of a person and the state as a whole. Many factors affect it, such as psychological, sociological. All these factors affect us in different ways, depending on the subjectivity and objectivity of the question. Many authors talk about the importance of how older people interpret the financial connection with their families and how they define and have an understanding of financial well-being, as it will help better understand their motivations that emphasize their financial behavior. Such detailed analysis can only be achieved by conducting qualitative research. Therefore, to understand the concept of financial well-being, modern research is based on a qualitative definition of the financial well-being of older people, based on the perception of the past experience of the processes of financial socialization of the family. In the result, it will help shed light on the financial well-being and behavior of older people and the impact of their relationships with parents and children on today's well-being.

\section{Methodology}

This study is based on the theory of family financial socialization discussed in the study of Gudmunson and Danes (2011) [17]. A tent to inherent cognitive processes was taken, which was implied by elderly people to determine and understand financial wellbeing and family financial context, where the cognitive processes have been founded. In current research, there are developed seven main blocks, each one consists of several questions: life;

1. Financial well-being in different areas of

2. Participants perspective on financial well-
3. Participants perspective on ways of achieving financial well-being;

4. Family financial processes - in younger ages;

5. Access to finance;

6. Learn from their own experience;

7. Responsibility for financial well-being in old ages.

The data for the study were collected from interviews with 12 pensioners aged 60 years and older. The representativeness of the respondents was ensured by the factor of the ratio of male and female pensioners, i.e., according to the Bureau of National Statistics, $30 \%$ of male pensioners and $70 \%$ of women pensioners. This means that 4 men and 8 women participated in the interview. Participants were selected according to the age this research aims to study the effect of financial wellbeing of pensioners on the relationship between parents and children of elderly people (pensioners). How it affects the relationship of their children and grandchildren.

Interview types are determined based on the purpose. According to the intended purpose:

- retrospective interview whichisaimedat an evaluative reproduction of past facts, events by participants or witnesses of the situation. In this study, questions exposit past experience of pensioners in the financial literacy of their parents and relatives, in order to understand whether this has somehow influenced their financial well-being now.

- introspective interview, the purpose of which is to study the mindset and assessments of people about current events. Namely through the use of the questions of currents study, the financial wellbeing of pensioners and its impact on relationships in the family were identified and assessed.

- projective interview reveals possible public perception of virtually possible events or their behavior in potentially possible situations, thus a question was asked about what pensioners would do if they had high financial well-being.

After the purpose of the interview has been explained and procurement of consent to interview, there have provided private open and semistructured interviews. Interviews lasted from 20 to 45 minutes, some have been provided on the phone, some personally. All interviews started with offering to participants to give a definition to financial well-being and have more information on what has influenced their definition. Interviews ended with acknowledgment of participants and a reminder about the privacy of the interview. Twelve interviews have been recorded and stenographer. The names of participants have been changed. Atlas.ti software has been used for data analysis. being; 
The sample includes 6 interviews with men and 6 with women whose age is $60+$. The ethnic composition of 12 participants consists of 9 Kazakhs (90\%), 1 Russian (10\%), 1 polish, and 1 germen. Among them, four participants have higher medical education, one higher philological, three vocational education. One of them was a military whose experience was 20 years. Total work experience of the restof each interviewee made up more than 30 years. All of them are working pensioners. One of them is single, lived alone; two of them lived with children and parents. The remaining9 lived with their children and grandchildren.

Throughout the whole analysis research focused on using direct words and participants'descriptions in the conclusion. During the process, there have considered different imagespensioners have about financial well-being. These truths demonstrated and denied a theoretical conception. While investigating pensioners' opinions, which go beyond the theoretical concepts and conceptions of theory of Family Financial Socialization, they were not denied, moreover they were acknowledged under different conditions.

Thereby coding has been used, which determined three sub-categories, which were added to the adapted theory of FFS and hadthe following coding: (1) values development, (2) self-efficacy and (3) breeding/upbringing. hey have also developedthe following 5 categories, which have been adapted to the theory of FFS: (1) limitations, (2) stability (e.g., life independently of own state), (3) Strategies, favoring financial well-being (e.g., saving money for future), (4) factors which disrupt or prevent an individual to achieve financial results and financial well-being, and (5) hindsight/retrospective analysis (that is the comprehension that financial state or an event only after it happened). During the study, there was such a category as the ability to live without bank loans/ loans.

Summarizing, the research algorithm should be described. At the first stage, there will be provided analysis of the number of pensioners at the second stage there will be an evaluation of financial position of pensioners in Kazakhstan. First, statistical data collected from the National Statistics Office will be analyzed. Based on this data the dynamics of the number of pensioners and their average pensions will be determined. The third stage will include an evaluation of the impact ofpensioners' financial well-being on their family lives, which will be conducted through interviews. On the basis of the results of the analysis, it will be possible to assess the general condition of pensioners and understand what steps need to be taken to improve the situation of the elderly in the country.

\section{Results and discussion}

As of January 1, 2020, there were 2,251,301 pensioners in Kazakhstan, which is $8.4 \%$ of the total population. The largest number of pension recipientsis in the East Kazakhstan region. Their number is equal to 236945 people, next in the Almaty region and in the city of Almaty, 234635 and 232556 people, respectively.

As can be seen from Table 2, most pensioners live in the North Kazakhstan region, their share is $19 \%$ in 2020 and the increase over 10 years is $3.7 \%$. Population decline is observed in this region. During 10 years, the population in this region has decreased by $8 \%$, and the number of pensioners has increased by $12.7 \%$. Zhambyl region is in second place with an increase of 3.4\%, the number of their pensioners increased from $9 \%$ to $12.4 \%$. In the third place, East Kazakhstan region with a $3 \%$ increase. Here, the situation is the same in the North Kazakhstan region, the population is falling, and the number of pensioners is growing. Additionally, only in Almaty, there is a decrease in the share of pensioners in the population of the city because this city has one of the highest population growth after Nur-Sultan.

In regions with population problems, various resettlement programs are being implemented, but they have not yet solved the existing problems.

Because these regions are aging and need the right policies and solutions to these problems. Therefore, such issues need to be addressed not only at the state level but also at the local level.

According to data collected from the Bureau of National Statistics, the average pension in Kazakhstan in 2020 was 63,937 KZT. As demonstrated in figure 1, over the past twenty years, the average pension has increased by $148.7 \%$. That is the pension has increased from $4298 \mathrm{KZT}$ in 2000 to $63,937 \mathrm{KZT}$ in 2020. Such changes developed due to the reforming of thepension system, social policy and general economic recovery. Also, because of the funded component of the pension, i.e., these are $10 \%$ that are deducted to the UNPF from the salary of each working citizen.

Next,theanalysiswillusea 10-yearperiod, from 2010 to 2020. In table 1, therearegivenstatisticson the average monthly pensions by region. There we can be distinguished 5 regions and cities where pensioners receive a high pension. These are the cities of republican significance Nur-Sultan (80114 KZT) and Almaty (76394 KZT), and the industrial regions of the country East Kazakhstan region (71,330 KZT), followed by Karaganda region with 68,103 KZT and Pavlodar region with 66,059 KZT. These figures are associated with high employment and average wages in these regions. 
ФИНАНСЫ И УПРАВЛЕНЧЕСКИЙ УЧЕТ, БУХГАЛТЕРСКИЙ УЧЕТ

Table 1 - Growth rates of pensioners in relation to the population as a whole by region, for 2010 and 2020

\begin{tabular}{|c|c|c|c|c|c|c|c|c|c|}
\hline \multirow[b]{2}{*}{ Region } & \multicolumn{3}{|c|}{$\begin{array}{c}\text { Number of pension recipients, } \\
\text { people }\end{array}$} & \multicolumn{3}{|c|}{ Population size, people } & \multicolumn{3}{|c|}{ Shareofpensioners, $\%$} \\
\hline & 2010 & 2020 & 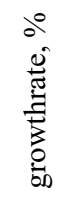 & 2010 & 2020 & 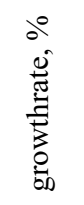 & 2010 & 2020 & 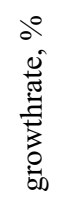 \\
\hline $\begin{array}{l}\text { TheRepublic of } \\
\text { Kazakhstan }\end{array}$ & 1695301 & 2251301 & 24,6 & 16203274 & 18631779 & 13 & 10,5 & 12 & 1,5 \\
\hline Akmola & 96474 & 112842 & 14,5 & 735134 & 736735 & 0,2 & 13,1 & 15,3 & 2,2 \\
\hline Aktobe & 68340 & 95407 & 28,3 & 763591 & 881651 & 13,4 & 9,2 & 10,8 & 1,6 \\
\hline Almaty & 165905 & 234635 & 29,3 & 1836162 & 2055724 & 10,6 & 9 & 11,4 & 2,4 \\
\hline Atyrau & 42746 & 61428 & 30,4 & 520988 & 645280 & 19,3 & 8,2 & 9,5 & 1,3 \\
\hline West Kazakhstan & 71864 & 91271 & 21,3 & 603858 & 656844 & 8,1 & 11,9 & 13,9 & 2 \\
\hline Zhambyl & 93737 & 128083 & 26,8 & 1034487 & 1130099 & 8,5 & 9 & 12,4 & 3,4 \\
\hline Karaganda & 177177 & 207498 & 14,6 & 1352217 & 1376882 & 2,2 & 13,1 & 15 & 1,9 \\
\hline Kostanay & 118948 & 137097 & 13,2 & 881656 & 868549 & $-1,5$ & 13,5 & 15,8 & 2,3 \\
\hline Kyzylorda & 52422 & 75868 & 30,9 & 700511 & 803531 & 12,8 & 7,5 & 9,4 & 1,9 \\
\hline Mangystau & 31065 & 55156 & 43,6 & 503241 & 698796 & 28 & 6,2 & 7,9 & 1,7 \\
\hline South Kazakhstan & 172548 & - & - & - & - & - & -- & - & - \\
\hline Pavlodar & 98436 & 118328 & 16,8 & 744395 & 752169 & 1 & 16,6 & 15,7 & $-1,1$ \\
\hline North Kazakhstan & 90836 & 104014 & 12,7 & 592791 & 548755 & -8 & 15,3 & 19 & 3,7 \\
\hline Turkestan & - & 174898 & - & - & 2016037 & - & & 8,6 & - \\
\hline EastKazakhstan & 200184 & 236945 & 15,5 & 1398073 & 1369597 & -2 & 14,3 & 17,3 & 3 \\
\hline Nur-Sultancity & 45279 & 103130 & 56 & 649152 & 1136156 & 42,9 & 7 & 9 & 2 \\
\hline Almatycity & 169340 & 232556 & 27,1 & 1390610 & 1916822 & 27,5 & 12,2 & 12,1 & $-0,1$ \\
\hline Shymkentcity & - & 82145 & - & - & 1038152 & - & & 7,9 & - \\
\hline
\end{tabular}

Note - Compiled by the author according to the Bureau of National Statistics.

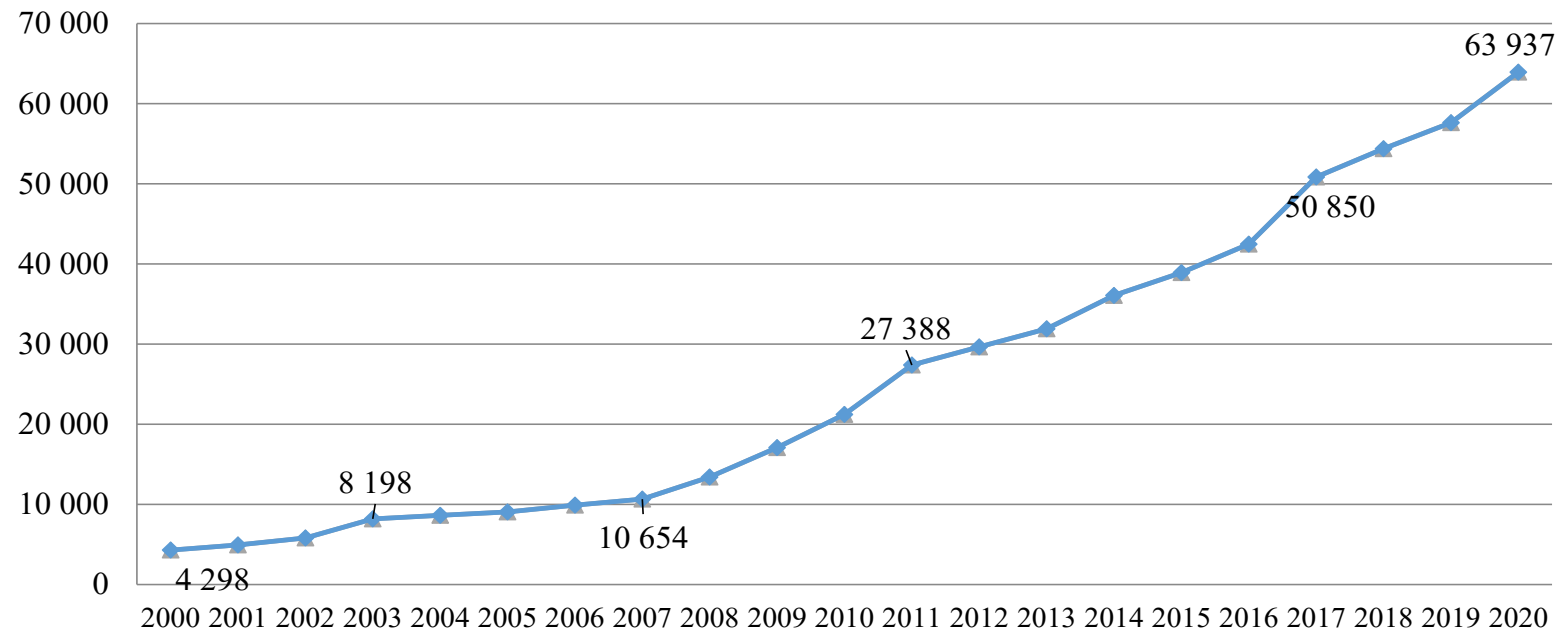

Figure 1-Average monthly assigned pensions in Kazakhstan, KZT, 2000-2020

Note - Compiled by the author according to the Bureau of National Statistics. 


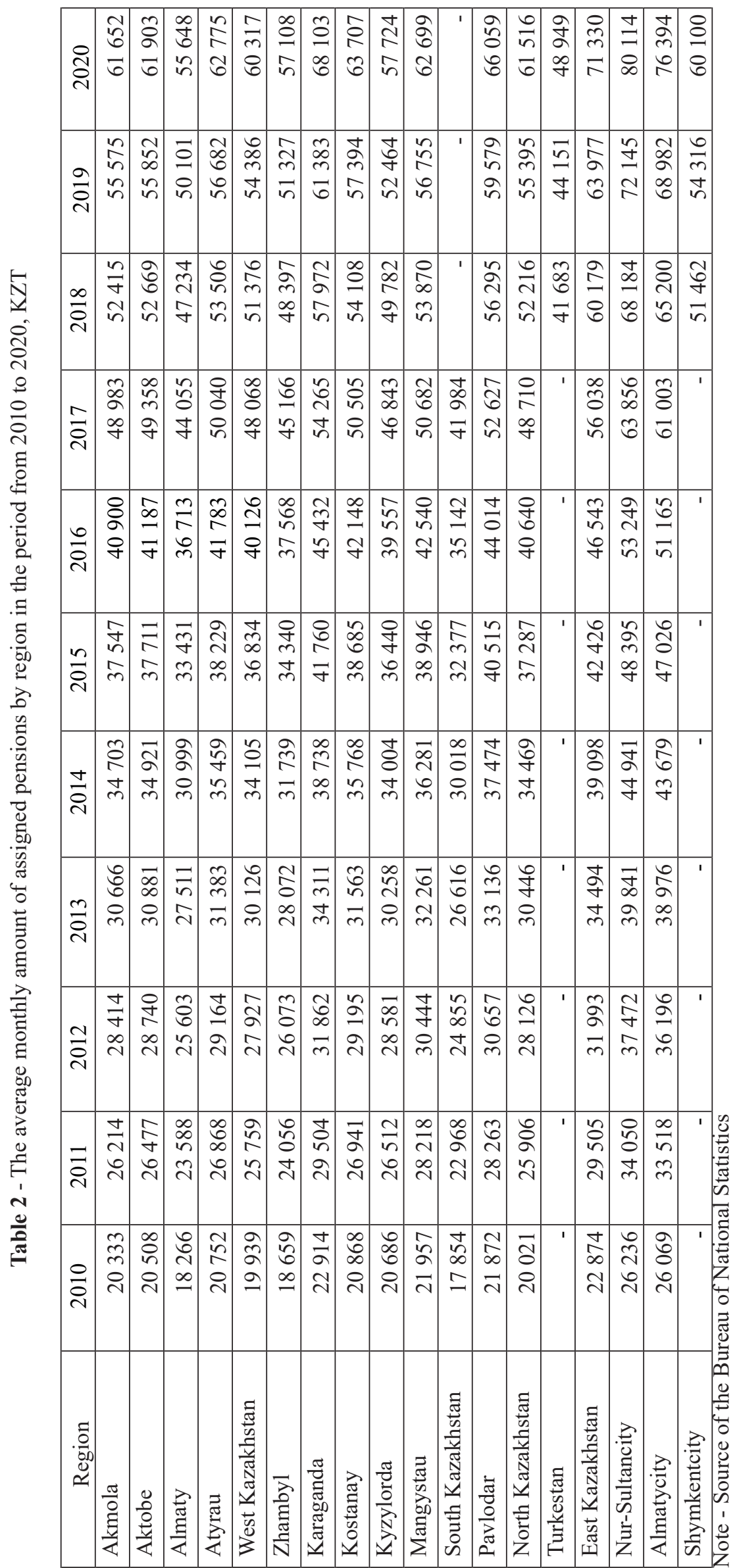


The lowest average pension is received by pensioners of the following regions: Turkestan (48949 KZT), Aktobe (55648 KZT), Zhambyl $(57108$ KZT) and Kyzylorda (57724 KZT). This is associated with the fact that specifically southern regions such as Turkestan, Dzhambyl and Kyzylorda have the lowest nominal monetary incomes. This figure does not exceed 100 thousand KZT there: Turkestan region $(65.9 \mathrm{KZT})$, then comes to the city of Shymkent (79.1 KZT), Zhambyl (86.5 KZT), Almaty (90.7 KZT) and Kyzylorda (91.2 KZT) area. As well as high and low employment, i.e. unemployment.

Generally, countrywide there has seen a marked increase in average monthly pensions within $10 \%$ in all regions. This is due to the annual decrees of the head of state to increase pensions from $7 \%$ to $10 \%$.

Table 3 - The ratio of the average level of pension to the minimum wage and the average wage of employees, KZT

\begin{tabular}{|l|c|c|c|c|c|c|c|c|c|c|c|}
\hline \multicolumn{1}{|c|}{ Years } & 2010 & 2011 & 2012 & 2013 & 2014 & 2015 & 2016 & 2017 & 2018 & 2019 & 2020 \\
\hline $\begin{array}{l}\text { Averagepensionper } \\
\text { month }\end{array}$ & 21238 & 27388 & 29644 & 31918 & 36068 & 38933 & 42476 & 50850 & 54387 & 57622 & 63937 \\
\hline Averagesalary & 77611 & 90028 & 101263 & 109141 & 121021 & 142898 & 150827 & 162673 & 186815 & 233136 & 230829 \\
\hline $\begin{array}{l}\text { The ratio of the } \\
\text { average pension } \\
\text { level to the average } \\
\text { salary,\% }\end{array}$ & 23,6 & 27,1 & 27,1 & 26,4 & 25,2 & 25,8 & 26,1 & 27,2 & 23,3 & 24,9 & 23,6 \\
\hline $\begin{array}{l}\text { The ratio of } \\
\text { the average } \\
\text { pension level to } \\
\text { the subsistence } \\
\text { minimum,\% }\end{array}$ & 157,4 & 170,4 & 176,2 & 179,4 & 189,1 & 198,16 & 196,5 & 213,8 & 200,8 & 196,3 & 193,6 \\
\hline
\end{tabular}

Note - Compiled by the author according to the Bureau of National Statistics

To determine the financial well-being of pensioners, two indicators are the purchasing power of the average assigned pension and the replacement rate. The indicator "purchasing power of the average assigned pension" is the ratio of the average assigned pension to the subsistence minimum of pensioners. It reflects the potential of the population to purchase goods and services and is expressed through the commodity equivalent of a pension. Additionally, the replacement rate is calculated as the ratio of wages to pension, in this study these are the average values for the country. This indicator evaluates the adequacy of the pension system and is used to determine the targets of the pension policy. According to the convention adopted by the ILO on the minimum standard of social protection, the replacement rate should not be less than $40 \%$

In table 3, there are given indicators of the replacement rate during 2010-2020, which varies from 23.6 to 27.2 , which indicates a large gap between the average pension and the average salary, and that pensioners have low financial opportunities according to international standards. Talking about purchasing power, from 2010 to 217 , a positive trend is observed. However, in 2018, there is a decline of $13 \%$, and in the following years to $193.6 \%$, which is characterized by changes in the calculation of pensions from 2018 .
On the whole, pensioners in the country must survive, even annual pension rise is unhelpful since prices for housing and communal services, food, and essential goods immediately rise. Proof of that can be the answers of one of the respondents, who noted that in January 2021, the pensions of pensioners were slightly increased. In Januaryrespondents received an allowance of eight thousand KZT, but since the same month prices for housing, electricity tariffs, and the cost of food has increased. The premium, according to the pensioners, is not felt at all like a drop in the ocean. Additionally, given the salaries of Kazakhstanis, not everyone has the opportunity to withdraw part of their pension.

The results of the interviews of this study will be discussed further.

On the basis of the results of the interview and its coding, the following factors were identified that affect the financial well-being of pensioners (See Fig.2)

- Education;

- Family composition (number of people in the family: large family);

- Pension size;

- Other sources of income (deposits);

- Real estate (house, apartment)

- Help from children and relatives (household and financial help); 
- State social policy;

- Influence of parents;

- Impact of successful people (success stories)

- Movable property (vehicles)

- Financial literacy
Education for the respondentsis the key factor as their income depended on it. With regard to the level of their education, $30 \%$ had a secondary specialized education, and the remaining $70 \%$ higher. Driven by USSR social policy and parents they received a decent education since the parents wanted their children to live in better conditions.

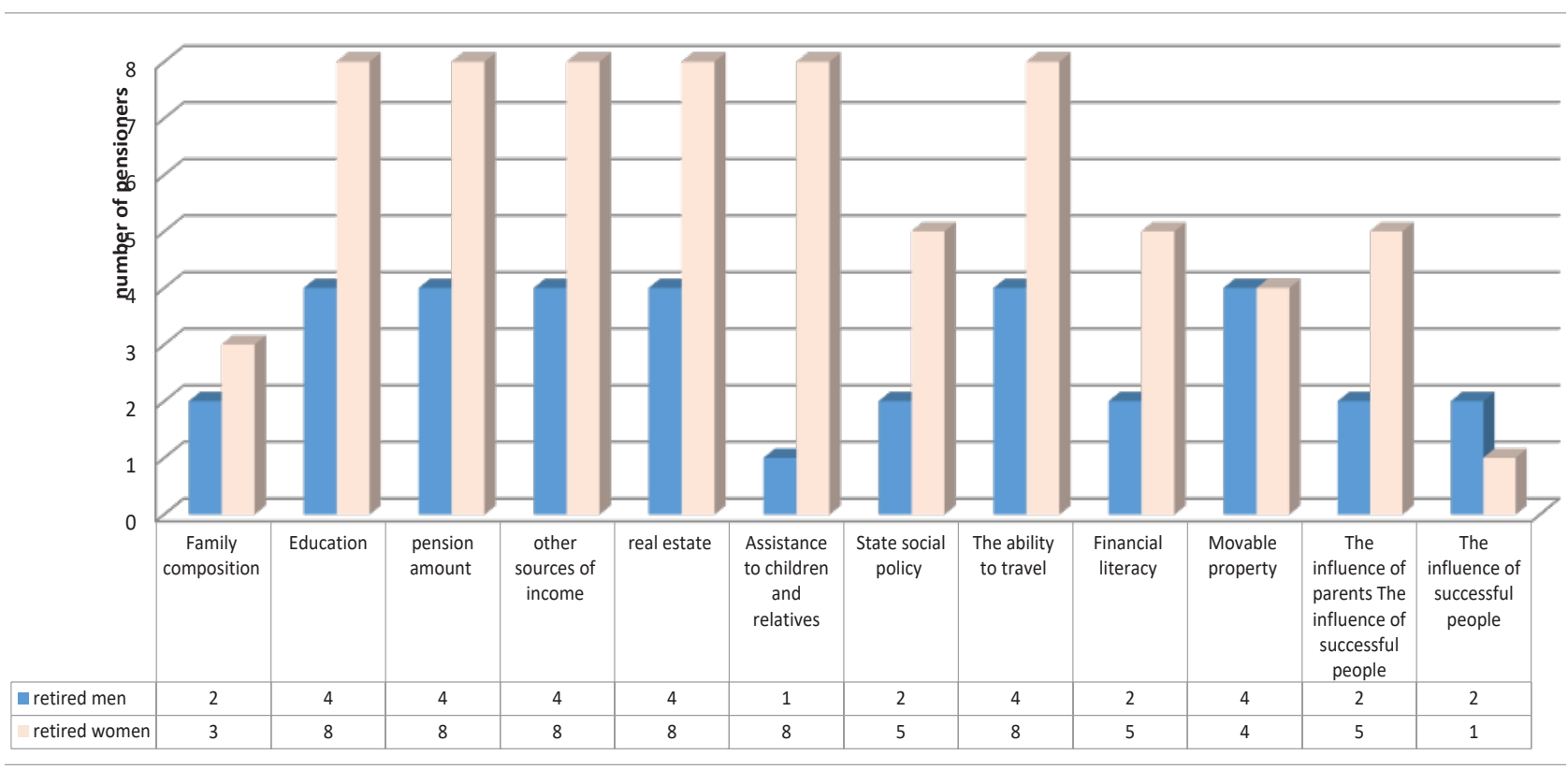

Figure 2 - Factors affecting the financial well-being of pensioners

Noteт - Compiled by the author.

According to Gudmunson and Danes (2011) it is thought that much of their free time family members spend altogether communicating with one another during their vocation, and so thus they forge strong and healthy relationships among themselves [17]. Having a recollection of their own family relations and, participants have shared that their parents were busy at work and they did not have financial knowledge or skills. All they knew was working hard and then everything would be well.

The reason was that in Soviet times everyone was sure that the government would take care of them. That influenced their financial well-being in pension age. Serido and Deenanath (2016) state that children usually repeat financial behavior after their parents, which they demonstrate and children observe and repeat that [29]. Thereupon it was crucial to gain insight into financial operations types that people did, who were around them during the process of adulating.

For instance, the participants have stated that their parents have given one hundred and ten percent for their children to obtain higher education because education could help them improve their well-being, that a good profession is fundamental for passing to another social level. Example 3:

"We grew up independently, on our own, as we come from a family with multiple children. Our parents were always at work to provide us with necessary things. Those were hard times, must thank them for their support. Everything that I have achieved is their merit. My father used to say that we must have higher education, and knowledge is light. Furthermore, if we have to obtain education, we can build our lives better that they did. Leave to the city, settle down there. Go for one social level higher, than them. We tried delivering all their expectations. They gave us the opportunity to graduate school and obtain higher education."

Nevertheless, all of them have said that their parents did unteach them how to manage their finances. Some thought the reason was that they come from multichildren families and parents did not have time for that, as they must provide for their family. So, for instance, $C$ said:

«Nothing of the kind at that time. We have a multichildren family. We could even go to the cinema for 5 coins. We struggled through hard times. Therefore, we saved on everything. We 
wore each other's clothes, half-starved, but were happy. We hoped for the best. Elder as they grew up helped our parents and tried giving a start to younger ones. Because our parents used to say that we are responsible for each other and must always support and help each other. So we took them as an example, but we saved less, probably because there were fewer children."

Mostly, everybody thinks that the main reason was that they lived in times of the Soviet Union. According to L:

"At the time of my parents, everything was stable. Education was compulsory, if you graduated institute then must get a job, and consequently good pension and social goods in old age. So, nobody thought of savings. Today, of course, there is no stability and you worry about your children and grandchildren."
What is more, it is clear that one of the key factors is social policy, namely education availability, the number of jobs, level of pensions and benefits. The direction of state social policy is highly important because the population confidence in government depends on it.

Another important factor is success stories of strangers, which pensioners would like to take cues from, but unfortunately, for a number of reasons, such as age and low level of financial literacy, they cannot repeat their successful path.

Family members obtain financial socialization only when they intercommunicate. In this sample, pensioners have mentioned restrictions on implicit socialization. Namely, participants have emphasized that they have learned to manage finance from their parents while observing their actions and instructions Gudmunson and Danes (2011

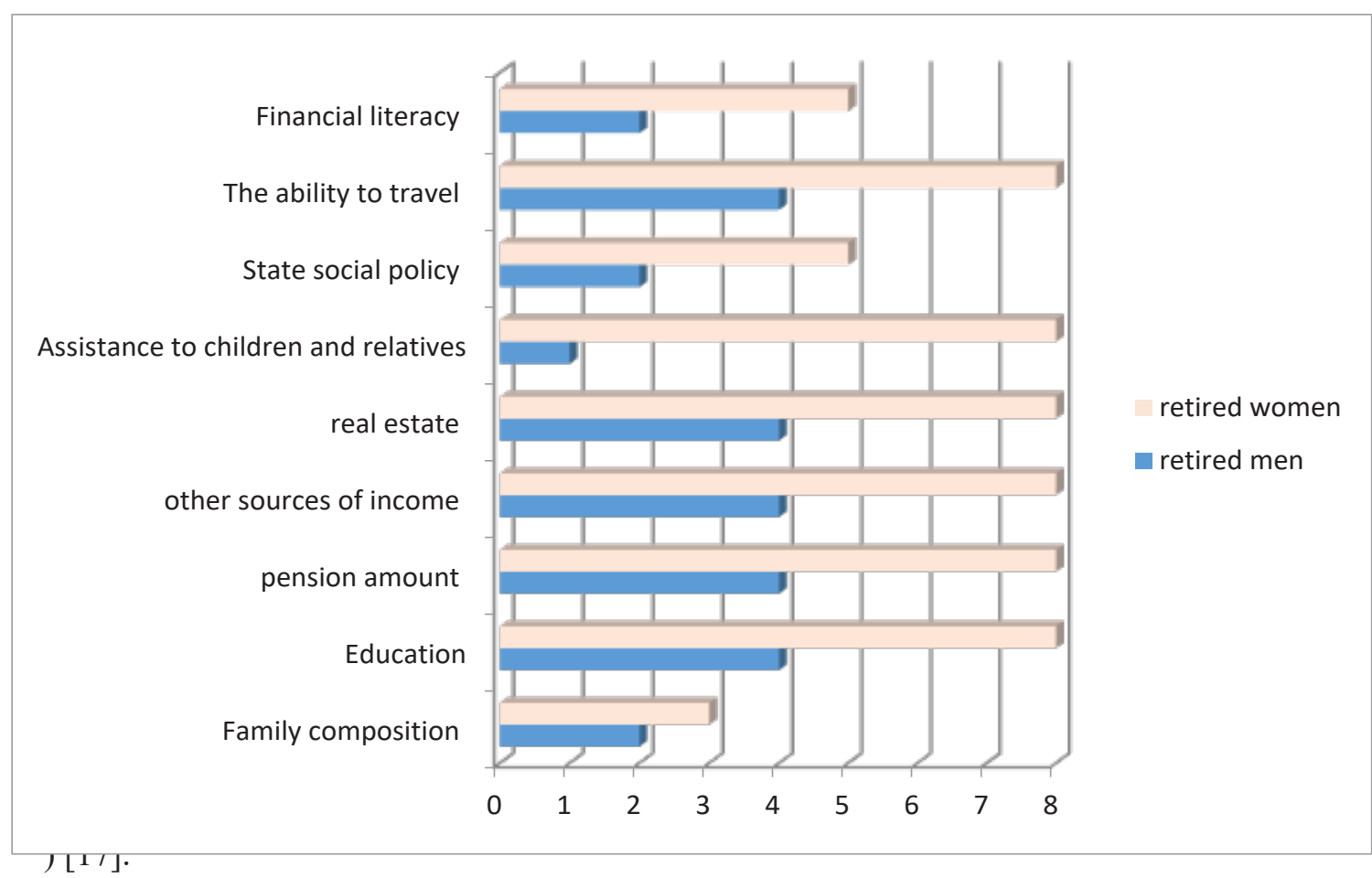

Figure 3 - the impact of financial well-being on different spheres of life of pensioners, in the context of men and women.

Note-compiled by the author.

They added, that they do unteach their children questions of finance, because time changes rapidly and they do not have current knowledge and skills. Moreover, their children are more aware of these issues and help them. It is due to the rapid development of information technology.
From the interview analysis, it is clear that financial well-being can influence following sectors of life of a pensioner (See Fig.3):

- family relationships

- social relationships

- charity

- physical condition / health 
- psychological / mental state

- life satisfaction

- for the opportunity to receive benefits (the ability to travel, buy expensive things)

- personal development.

Projective interview questions as what pensioners would do if they had a high level of financial well-being? They answered that they would help their families - it is $60 \%$, they would do charity - 30\%, $10 \%$ said that they would donate their finances to protect the environment because they would like to preserve it for future Questions concerning current financial well-being majority of pensioners $(80 \%)$ rated the questions as average, $10 \%$ - above the average, $10 \%$ below the average.

Also, financial well-being has influence on physical condition (health) of pensioners. $70 \%$ of interviewed said that if they had a sufficient level of financial well-being, they would take care of their health and fitness with professionals in this field. $10 \%$ said that their physical condition depends mainly on themselves because they can play sports and everything else on their own. All respondents agreed in governmental medical treatment insufficiency, that most medicine they must buy themselves, that they need to buy the bulk of the medicines themselves and their prices are very high.

Financial well-being has impact on all spheres of life and even on communication with friends, colleagues, and relatives. Pensioners want to lead an active social life, but all this requires additional expenses, which, unfortunately, are not enough at the moment.

They have added that they do unteach their children financial matters, this is because time changes rapidly and they do not have current knowledge and skills. Moreover, their children are more knowledgeable in these matters and help them.

Discussing the results of the interview, the task of which was to give a subjective definition of financial well-being and to determine the impact of financial well-being on family relationships of pensioners. The following conclusion can be:

1. Almost all pensioners have defined their financial well-being as "housing, transport, amount and diversity of food products," live without loans/credits, and opportunities to travel. To feel financially successful all that is missing is traveling, which pensioners in developed countries can afford. Saying that state can increase pension, because we are a rich country. Many have noticed a lack of financial literacy and have recommended teaching it from childhood.

2. Many of them have marked that they try helping their children to obtain education, buy hosing/flat and transport. To their grandchildren, they pay for their curricular classes and sports courses. Which they could not give to their children.

3. Only the pensioners who live apart from children said that she has everything she needs. Even more, she can save money and travel, because she does not have big expenses on food and clothes, because she lives alone. But, if she was unemployed, her pension would cover convenience expenses, the left amount would be spent on food, transport, health. Thus, limit herself inthe consumption of other goods.

4. Men consider that their family and social relationships depend on their financial well-being. Whereas women are firm that these relationships do unhinge on financial well-being. Men have also said that if their financial welling is good they feel more confident and the society reaches out for them.

This study showed the diversity of living standards and well-being of retirement-age people. It is necessary to set up measures to early recognition of pensioners who fell on hard times and provision of proper social service to improve their well-being. Apart from state social policy, it is important to organize future retirement well-being as early as in working rather than depending on the government.

\section{Conclusion}

The following results were obtained during the research. First, the number of pensioners in the country is growing, the largest number of pensioners live in the South of Kazakhstan and Almaty, which is almost $20 \%$ of the society number, and the smallest number live in the Mangystau region. Second, the assigned average monthly pensions are growing annually by $7-10 \%$ across the country, but this figure covers only inflation. Third, according to the statistical data, financial well-being in terms of purchasing power and replacement rate, they do not meet ILO standards. Generally, pensioners cannot afford many benefits due to their low financial situation.

This research paper attempted to explain the concept of financial well-being of pensioners through their subjective opinion. Also how it affects their family relationships. During studying this issue, it was revealed that for many pensioners, financial well-being is material well-being, i.e. to have money for all needs, to have a house or apartment, and to be able to travel abroad as a tourist. Most of them believe that their social status depends on their financial well-being, and it affects their relationship with the family, but to a small extent.

Although they rated their well-being average, and sometimes even below average, nevertheless, pensioners actively help their children-not only 
raise their grandchildren, but also share their meager pension payments with their children. And it is although only a few of them have additional earnings.

The main limitation was a small quantity of surveyed and time. Because respondents have work, and all of them have average financial wellbeing. Therefore, this data cannot be generalized. A group of unemployed pensioners needs to be added, as well as pensioners from regions and other categories.

\section{Reference}

1. Yan, S.J., Liu, Li, Shi, Lin, et al. (2013). Research progress on life satisfaction of the elderly in China. Chinese Nursing Research, 27 (9C), 1009-6493. doi:10.3969/j.issn.1009-6493.2013.27.003

2. Boisclair, D., Lusardi, A., and Michaud, P.C. (2017). Financial literacy and retirement planning in Canada. Journal of Pension Economics and Finance. 16, 277-296. https://doi.org/10.1017/S1474747215000311

3. Bruuggen, E. C., Hogreve, J., Holmlund, M., Kabadayi, S., and Leofgren, M. (2017). Financial well-being: a conceptualization and research agenda. Journal of Business Research, 79, 228-237. https://doi. org/10.1016/j.jbusres.2017.03.013

4. Skinner, J., (2007). Are you sure you're saving enough for retirement? American Economic Review, 21, 59-80. DOI: $10.1257 /$ jep.21.3.59

5. Bobe, B.J., and Cooper, B.J. (2018). Accounting students' perceptions of effective teaching and approaches to learning: impact on overall student satisfaction. Accounting and Finance, 60, 20992143. https://doi.org/10.1111/acfi.12364

6. Griggs, D., Stafford-Smith, M., Gaffney, O. et al. (2013). Sustainable development goals for people and planet. Nature, 495, 305-307. https://doi. org/10.1038/495305a

7. Dittmar, H., Bon,d R., Hurst, M. and Kasser T. (2014). The relationship between materialism and personal well-being: a meta-analysis. Journal of Personality and Social Psychology,107, 879-924. DOI:10.1037/a0037409

8. Porter, N.M. and Garman, E.T. (1992). Money as part of a measure of financial well-being. American Behavioral Scientist, 35, 820-826. https:// doi.org/10.1177/0002764292035006016

9. Shim, S., Barber, B.L., Card, N.A. et al. (2010). Financial Socialization of First-year College Students: The Roles of Parents, Work, and Education. Youth Adolescence, 39, 1457-1470. https://doi.org/10.1007/ s10964-009-9432-x

10.Kapur, B.K. (2005). Can faster income growth reduce well-being? Social Choice and Welfare, 25, 155171. https://doi.org/10.1007/s00355-005-0040-8

11. Malone, K., Stewart, S.D., Wilson, J. and Korsching, P.F.(2010). Perceptions of financial wellbeingamong American women in diverse families. Journal of Family and Economic, 31, 63-81. https://doi. org/10.1007/s10834-009-9176-5
12. Garman, E.T., Sorhaindo, B., Bailey, W., Kim, J., and Xiao, J. (2004). Financially distressed credit counseling clients and the in charge financial distress/ financial well-being scale. Proceedings of the Eastern Regional Family Economics and Resource Management Association Conference. 71-81.

13.Joo, S.H. and Grable, J.E, 2004, An exploratory framework of the determinants of financial satisfaction, Journal of Family and Economic, 25, 25-50. https://doi. org/10.1023/B:JEEI.0000016722.37994.9f

14. Judge, T.A., Ilies, R., and Dimotakis, N. (2010). Are health and happiness the product ofwisdom? The relationship of general mental ability to educational and occupational attainment, health, and well-being. Journal of Applied Psychology, 95, 454-468. https:// doi.org/10.1037/a0019084

15.Sacks, D.W., Stevenson, B., and Wolfers, J. (2012). The new stylized facts about income and subjective well-being. Emotion, 12, 1181-1187. https:// doi.org/10.1037/a0029873

16. Gudmunson, C.G., Danes, S.M. (2011). Family financial socialization: Theory and critical review // Journal of Family and Economic, 32, 644-667. https:// doi.org/10.1007/s10834-011-9275-y

17.Danes, S.M. (1994). Parental perceptions of children's financial socialization. Journal of Financial Counseling and Planning, 5(1), 27-146.

18. Lusardi, A. and Mitchell, O.S. (2011). Financial literacy around the world: an overview. Journal of Pension Economics and Finance, 10, 497-508. https:// doi.org/10.1017/S1474747211000448

19.Butt, A., Donald, M.S., Foster, F.D., Thorp, S., and Warren, G.J., 2017, Design of My Super default funds: influences and outcomes.Accounting and Finance, 57, 47-85. https://doi.org/10.1111/acfi.12134

20.Lin, C., Hsiao, Y.J., and Yeh, C.Y. (2017) Financial literacy, financial advisors, andinformation sources on demand for life insurance. Pacific-Basin Finance Journal, 4, 218-237. https://doi.org/10.1016/j. pacfin.2017.04.002

21.Banks, J., Blundell, R., and Tanner, S. (1998). Is there a retirement-savings puzzle? American Economic Review, 88, 769-788.

22.Earl, J.K., Gerrans, P., Asher, A., and Woodside, J. (2015). Financial literacy, financial judgement, and retirement self-efficacy of older trustees of self-managed superannuation funds.Australian Journal of Management, 40, 435-458. https://doi. org/10.1177/0312896215572155

23. Blanchflower, D.G. and Oswald, A.J. (2004). Well-beingover time in Britain and the USA. Journal of Public Economics, 88, 1359-1386. https://doi. org/10.1016/S0047-2727(02)00168-8

24. Vlachos, P.A., Tsamakos, A., Vrechopoulos, A.P., and Avramidis, P.K. (2009). Corporate social responsibility: attributions, loyalty, and the mediating role of trust. Journal of the Academy of Marketing Science, 37, 170-180. https://doi.org/10.1007/s11747008-0117-x

25.Ashby, J., Schoon, I., \& Webley, P. (2011). Linkages between saving behavior in adolescence and adulthood. European Psychologist, 16, 227237. https://doi.org/10.1027/1016-9040/a000067. 
26. Brown, S., Taylor, K. (2016). Early influences on savings behavior: British panel data. Journal of Bank Finance, 62, 1-14. https://doi.org/10.1016/j. jbankfin.2015.09.011

Walstad, W., Rebeck, K., \& Macdonald, R. (2010). The effects of financialeducation on the financial knowledge of high school students. Journal of Consumer Affairs, 44, 336-357. https://doi.org/10.1111/j.17456606.2010.01172.x
27.Xiao, J., O’Neill, B. (2016).Consumer financial education and financial capability. International Journal of Consumer Studies, 40, 712-721. https://doi. org/10.1111/ijcs.12285

28.Serido, J., Deenanath, V. (2016) Financial Parenting: Promoting Financial Self-Reliance of Young Consumers. In: Xiao J. (eds) Handbook of Consumer Finance Research. Springer, Cham. https://doi. org/10.1007/978-3-319-28887-1_24

\section{Information about the authors}

* Zaira T. Satpayeva - PhD, Institute of CS MES RK, e-mail: szt_kz@,mail.ru, ORCID ID: https://orcid.org/0000$\underline{0002-1644-3709}$

Assel S. Bekbossinova - PhD student, NARXOZ University, e-mail: assel.bekbossinova@,narxoz.kz, ORCID ID: https://orcid.org/ 0000-0003-1054-6640

Maira M. Ryskulova - NARXOZ University, PhD in Economics, Associate Professor, e-mail: maira.ryskulova@, narXoz.kz, ORCID ID: https://orcid.org/0000-0002-1944-5339

\section{Авторлар туралы мәліметтер}

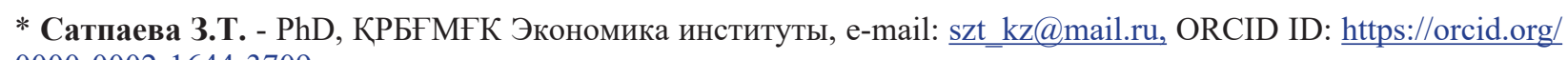
$\underline{0000-0002-1644-3709}$

Бекбосинова А.С. - докторант, НАРХОЗ университеті, e-mail: assel.bekbossinova@narxoz.kz, ORCID ID: https://orcid.org/ 0000-0003-1054-6640

Рыскулова М.М. - э.ғ., ассоц. профессор, НАРХО3 университеті, e-mail: maira.ryskulova@narxoz.kz, ORCID ID: https://orcid.org/0000-0002-1944-5339

\section{Сведения об авторах}

* Сатпаева 3.T. - PhD, Институт экономики MOH PK, e-mail: szt kz@,mail.ru, ORCID ID: https://orcid.org/ $\underline{0000-0002-1644-3709}$

Бекбосинова А.С. - Университет НАРХO3, докторант, e-mail: assel.bekbossinova@narxoz.kz, ORCID ID: https://orcid.org/ 0000-0003-1054-6640

Рыскулова М.М. - к.э.н., ассоц.профессор, Университет НАРXО3, e-mail: maira.ryskulova@narxoz.kz, ORCID ID: https://orcid.org/0000-0002-1944-5339 